\title{
Studies on the Effect of Heterosis for Yield and Yield Contributing Plant Traits in Tomato (Solanum lycopersicum L.)
}

\author{
Prachi Pattnaik*, Anand Kumar Singh, Bajrang Kumar, \\ Diksha Mishra and Binod Kumar Singh
}

Department of Horticulture, Institute of Agricultural Science, Banaras Hindu University, Varanasi-221005, Uttar Pradesh, India

\begin{tabular}{l} 
Ke y w o r d s \\
Heterosis, \\
Genotypes, \\
$\begin{array}{l}\text { Significant, } \\
\text { Tomato, Yield }\end{array}$ \\
Article Info \\
$\begin{array}{l}\text { Accepted: } \\
\text { 04 March } 2020 \\
\text { Available Online: } \\
10 \text { April } 2020\end{array}$ \\
\hline
\end{tabular}

Keywords

Heterosis,

Genotypes,

Significant,

Tomato, Yield

Accepted:

04 March 2020

10 April 2020

\section{A B S T R A C T}

A set of 24 cross combinations were developed through Line $\times$ Tester mating system involving 11 diverse genotypes of tomato and observations were taken for yield and yield attributing characters to study the extent of heterosis in the crosses. Tomato is an autogamous crop and has originated in the Peru region of South America. The experiment was conducted in Randomized Complete Block Design (RCBD) with three replications. The analysis of variance revealed that there was a significant genotypic difference among the genotypes under study, showing considerable amount of genetic variability among them. The lines under study were found significant for all traits under consideration. Significant differences due to testers were observed for all traits except days to $50 \%$ flowering, number of primary branches per plant and number of fruits per plant.Out of 24 combinations 10 crosses showed significant negative heterosis over better parent for days to $50 \%$ flowering and cross VRT-101-A $\times$ Pant T-5 ($15.96 \%$ ) followed by CTS-07 $\times$ Arka Abha (-15.73\%) and Angha $\times$ Pant T$5(-13.83 \%)$ recorded maximum negative significant heterosis. The cross combination Solan Vajra $\times$ Arka Abha, CTS-07 $\times$ Arka Abha and VRT101-A $\times$ Arka Abha exhibited maximum per cent of positive significant heterobeltiosis in the extent of $23.30,19.22$ and $16.62 \%$ respectively in case of fruit yield.

\section{Introduction}

Tomato (Solanum lycopersicum L.) with chromosome number $2 n=2 x=24$ is one of the most important and widely traded vegetable crop all over the world. It is an autogamous crop and has originated in the Peru region of South America. In many countries it is also 
labeled as "Poor man's orange" due to its alluring appearance and high nutritive value (Singh et al., 2004).Globally tomato ranks second in importance following potato but tops the list in processed vegetables (Chaudhary, 1996). To cope up with the everincreasing demand for vegetable in market and processing industries, it has become necessary to develop hybrids which have a complex of valuable attributes, viz., earliness, uniformity, better quality, higher yield, resistance to diseases and pest and adaptability to wider environmental conditions. The relative ease in conducting emasculation, high percentage of fruit setting and favourable number of seeds per fruit in tomato facilitates the exploitation of heterosis. Hedrick and Booth (1907) first observed heterosis for number of fruits per plant as well as higher yield per plant in tomato. But there is a lack of good hybrids especially in public sector. So, development of hybrid varieties of tomato is highly needed to support the farmer's interest. Therefore, the present investigation was conducted using Line $x$ Tester experimental design to identify the best cross combinations for yield and yield attributing plant traits in Tomato.

\section{Materials and Methods}

The current experiment was conducted at the Vegetable Research Farm, Department of Horticulture, Institute of Agricultural Sciences, Banaras Hindu University, Varanasi during rabi seasons of 2017-18 and 201819.The experimental material consisted of eight lines viz., CTS- 07, Angha, Solan Vajra, VRT-101-A, VRT-01, CO-3, VRT-06, H-8878-1 and three testers namely ArkaAbha, Pusa-120, Pant-T5 which were collected from Department of Horticulture, Banaras Hindu University, Varanasi. The materials were selected on the basis of variability present in them when observed phenotypically. The crossing programme was carried out during the rabi season of $2017-18$ by Line $\times$ Tester mating design from which 24 cross combinations were obtained. The $F_{1}$ along with their 11 parents were sown in the next season (2018-19) for their evaluation and generation of data. The experiment was laid out in Randomized Complete Block Design (RCBD) with three replications. All the recommended cultural practices and plant protection methods were undertaken to raise a successful crop. Observations were taken for seven plant and yield characters viz., days to $50 \%$ flowering, plant height $(\mathrm{cm})$, number of primary branches per plant, number of fruit clusters per plant, number of fruits per cluster, number of fruits per plant and fruit yield $(\mathrm{q} / \mathrm{ha})$. The statistical analysis of various parameters was done according to Panse and Sukhatme (1967).

\section{Results and Discussion}

The analysis of variance implicates the presence of sufficient amount of variation for most of the traits in both lines and testers. The mean sum of squares due to parents was all significant for all the seven traits. The lines under study were found significant for all traits under consideration. Significant differences due to testers were observed for all traits except days to $50 \%$ flowering, number of primary branches per plant and number of fruits per plant.The mid parent heterosis and heterobeltiosis for all the genotypes for the seven traits are presented in Table 1 and 2. Usually positive heterosis is considered desirable for maximum number of traits but in case of trait like days to $50 \%$ flowering, negative heterosis is considered highly desirable. From the analysis, it was revealed that the range of heterosis over mid and better parent for this trait varied from 17.28 (VRT-101-A $\times$ Pant T-5) to $2.86 \%$ (Solan Vajra $\times$ Pant T-5) and $-15.96($ VRT101-A $\times$ Pant T-5) to $11.11 \%$ (Solan Vajra $\times$ Pant T-5) respectively. A set of 11 out of 24 
crosses expressed significant negative heterosis over mid parent in case of days to 50 $\%$ flowering whereas 10 crosses showed negative significant heterosis over better parent. Highest significant negative heterosis over mid parent was found in the cross VRT101-A × Pant T-5 (-17.28 \%) followed by VRT-101-A $\times$ Arka Abha (-16.58 \%) and CTS-07 $\times$ Arka Abha (-16.20\%) whereas the cross combinations VRT-101-A $\times$ Pant T-5 ($15.96 \%$ ) followed by CTS-07 $\times$ Arka Abha ($15.73 \%)$ and Angha $\times$ Pant T-5 (-13.83 \%) recorded maximum negative significant heterobeltiosis. Such negative significant heterosis for this trait was also reported by Sekhar et al., (2010); Islam et al., (2012); Chauhan et al., (2014) and Dagade et al., (2015).

The average heterosis for plant height ranged from $-7.94($ CTS-07 $\times$ Pant T-5) to $71.65 \%$ (Angha× Pusa-120). Among the crosses, 14 crosses showed positive significant heterosis over mid parent for plant height and out of them, the cross Angha $\times$ Pusa-120 (71.65\%) followed by VRT-101-A $\times$ Pusa-120 (52.02 $\%)$ and CTS-07 $\times$ Pusa-120 (47.72 \%) exhibited maximum significant heterosis in the desired direction. Heterosis over better parent for this trait ranged from -13.66 (Solan Vajra $\times$ Pusa-120) to $50.82 \%$ (VRT-101-A $\times$ Pusa-120). Maximum significant heterosis over better parent for plant height was exhibited by the cross VRT-101-A $\times$ Pusa$120(50.82 \%)$ followed by Anghax Pusa-120 $(45.75 \%)$ and CTS-07 $\times$ Pusa-120 (38.36 \%). Experiment conducted by Singh et al., (2007); Soleiman et al., (2013); and Amin et al., (2017) also reported similar results on plant height.

Heterosis over mid parent for number of primary branches per plant ranged from 19.57 (VRT-06 × Pant T-5) to $51.72 \%$ (CTS$07 \times$ Pusa-120). Out of 24 crosses, maximum per cent of significant average heterosis was observed for the cross CTS-07 $\times$ Pusa-120 $(51.72 \%)$ followed by Solan Vajra $\times$ Arka Abha (41.67\%) and CO-3 × Pusa-120 (32.67 $\%)$. Similarly the range of heterosis over better parent varied from -30.19 (VRT-06 $\times$ Pant T-5) to $34.69 \%($ CTS-07 $\times$ Pusa-120). Seven out of 24 crosses showed positive significant heterosis over better parent.

Cross CTS-07 $\times$ Pusa-120 (34.69 \%) exhibited maximum significant heterobeltiosis followed by Solan Vajrax Arka Abha (34.21 $\%)$ and Angha $\times$ Pant T-5 (22.45 \%). The results of this finding were similar with the reports for higher number of branches per plant observed by Mohamed et al., (2012); Yadav et al., (2013); and Tamta et al., (2017).

Heterotic effect was observed in case of number of fruit clusters per plant both over mid parent and better parent with a range of 32.30 (VRT-01 $\times$ Pant T-5) to $42.38 \%$ $($ Angha $\times$ Pusa-120) and $-33.52($ VRT-01 $\times$ Pant T-5) to $41.73 \%$ (VRT-06 $\times$ Pusa-120) respectively. Higher number of fruit clusters per plant is beneficial for higher yield. The results revealed that significantly positive average heterosis was expressed by 17 crosses with maximum heterosis being exhibited by cross Angha $\times$ Pusa-120 (42.38 \%) followed by cross VRT-06 $\times$ Pusa-120 (41.83\%) and VRT-101-A $\times$ Pusa-120 (35.76\%) over mid parent.

Out of all the cross combinations obtained, 12 hybrids expressed significant positive heterosis over better parent for this trait. Maximum significant heterosis over better parent was exhibited by cross VRT-06 $\times$ Pusa-120 (41.73\%) followed by VRT-101-A $\times$ Pusa-120 (33.29 \%) and Angha $\times$ Pusa-120 $(27.61 \%)$. The works by Patwary et al., (2013) and Chauhan et al., (2014) also reported similar findings. 
Table.1 Estimation of heterosis over mid parent and better parent for days to 50\% flowering, plant height (cm) and number of primary branches per plant in tomato

\begin{tabular}{|c|c|c|c|c|c|c|}
\hline \multirow[t]{2}{*}{ Crosses } & \multicolumn{2}{|c|}{ Days to $50 \%$ flowering } & \multicolumn{2}{|c|}{ Plant height(cm) } & \multicolumn{2}{|c|}{$\begin{array}{c}\text { No. of primary branches per } \\
\text { plant }\end{array}$} \\
\hline & МPH & BPH & МPH & BPH & MPH & ВPH \\
\hline CTS-07 x ArkaAbha & $-16.20 * *$ & $-15.73 * *$ & $-3.89 *$ & $-4.72 * *$ & $24.14 * *$ & 10.2 \\
\hline CTS-07 x Pusa-120 & -5.68 & -4.6 & $47.72 * *$ & $38.36 * *$ & $51.72 * *$ & $34.69 * *$ \\
\hline CTS-07 x Pant T-5 & -6.01 & -3.37 & $-7.94 * *$ & $-12.71 * *$ & -2.27 & $-12.24 *$ \\
\hline Angha x ArkaAbha & $-12.90 * *$ & $-10.00 *$ & $-3.91 *$ & $-12.87 * *$ & $17.24 * *$ & 4.08 \\
\hline Angha x Pusa-120 & $-12.57 * *$ & $-8.05 *$ & $71.65 * *$ & $45.75 * *$ & 10.34 & -2.04 \\
\hline Angha x Pant T-5 & $-14.74 * *$ & $-13.83 * *$ & $25.23 * *$ & $18.46 * *$ & $36.36 * *$ & $22.45 * *$ \\
\hline SolanVajra x ArkaAbha & 0.58 & 6.17 & 0.93 & 0.05 & $41.67 * *$ & $34.21 * *$ \\
\hline SolanVajra x Pusa-120 & 1.19 & 4.94 & $-7.82 * *$ & $-13.66^{* *}$ & $27.78^{* *}$ & $21.05 * *$ \\
\hline SolanVajra x Pant T-5 & 2.86 & $11.11 *$ & $27.72 * *$ & $21.10 * *$ & -4.11 & -10.26 \\
\hline VRT-101 A x ArkaAbha & $-16.58 * *$ & $-13.33 * *$ & $39.40 * *$ & $28.58 * *$ & $23.60 * *$ & 7.84 \\
\hline VRT-101 A x Pusa-120 & $-13.04 * *$ & $-8.05 *$ & $52.02 * *$ & $50.82 * *$ & 10.11 & -3.92 \\
\hline VRT-101 A x Pant T-5 & $-17.28 * *$ & $-15.96 * *$ & $39.78 * *$ & $23.73 * *$ & $-13.33 *$ & $-23.53 * *$ \\
\hline VRT-01 x Pusa-120 & -4.49 & -2.3 & $24.86 * *$ & $8.65 * *$ & $17.65 * *$ & 6.38 \\
\hline VRT-01 x Pant T-5 & -4.86 & -3.3 & -1.23 & -3.91 & $-18.60 * *$ & $-25.53 * *$ \\
\hline CO-3 x ArkaAbha & $-8.99 * *$ & $-7.95 *$ & $26.50 * *$ & $18.18 * *$ & 6.93 & $-14.29 * *$ \\
\hline CO-3 x Pusa-120 & $-12.00 * *$ & $-11.49 * *$ & $37.31 * *$ & $36.51 * *$ & $32.67 * *$ & 6.35 \\
\hline CO-3 x Pant T-5 & $-14.29 * *$ & $-11.36 * *$ & $24.01 * *$ & $11.12 * *$ & $17.65 * *$ & -4.76 \\
\hline VRT-06 x ArkaAbha & 1.09 & 3.33 & $-6.57 * *$ & $-10.12 * *$ & 5.49 & -9.43 \\
\hline VRT-06 x Pusa-120 & 0.55 & 4.6 & $36.19 * *$ & $22.09 * *$ & $18.68 * *$ & 1.89 \\
\hline VRT-06 x Pant T-5 & -5.32 & -5.32 & 1.66 & 1.01 & $-19.57 * *$ & $-30.19 * *$ \\
\hline H-88-78-1 x ArkaAbha & -2.65 & 2.22 & $-7.73 * *$ & $-10.53 * *$ & $21.52 * *$ & $17.07 *$ \\
\hline H-88-78-1 x Pusa-120 & -1.08 & 5.75 & $27.81 * *$ & $15.43 * *$ & $26.58 * *$ & $21.95 * *$ \\
\hline H-88-78-1 x Pant T-5 & $-7.77 *$ & -5.32 & $6.19 * *$ & $4.64 *$ & $22.50 * *$ & $19.51 * *$ \\
\hline S.E.Diff & 0.98 & 1.13 & 1.37 & 1.58 & 0.15 & 0.18 \\
\hline CD $95 \%$ & 1.97 & 2.27 & 2.75 & 3.18 & 0.31 & 0.36 \\
\hline
\end{tabular}


Table.2 Estimation of heterosis over mid parent and better parent for number of fruit clusters per plant, number of fruits per cluster in tomato, number of fruits per plant and fruit yield (q/ha)

\begin{tabular}{|c|c|c|c|c|c|c|c|c|}
\hline \multirow[t]{2}{*}{ Crosses } & \multicolumn{2}{|c|}{$\begin{array}{l}\text { No. of fruit clusters per } \\
\text { plant }\end{array}$} & \multicolumn{2}{|c|}{ No. of fruits per cluster } & \multicolumn{2}{|c|}{ No. of fruits per plant } & \multicolumn{2}{|c|}{ Fruit yield (q/ha) } \\
\hline & MPH & ВPH & MPH & ВPH & МРН & ВРH & MPH & BPH \\
\hline CTS-07 x ArkaAbha & -0.45 & -3.32 & $-16.36 * *$ & $-25.14 * *$ & $32.95 * *$ & $18.34 * *$ & $22.18 * *$ & $19.22 * *$ \\
\hline CTS-07 x Pusa-120 & $21.90 * *$ & $21.86 * *$ & 5.44 & 3.44 & $10.76 * *$ & 0.62 & $23.14 * *$ & 15.09 ** \\
\hline CTS-07 x Pant T-5 & $-15.28 * *$ & $-26.48 * *$ & $12.26 * *$ & 4.18 & -0.82 & $-9.17 * *$ & $-3.92 *$ & $-13.07 * *$ \\
\hline Angha x ArkaAbha & $26.00 * *$ & $10.03 * *$ & $20.39 * *$ & $15.57 * *$ & $12.28 * *$ & $-9.99 * *$ & $-10.73 * *$ & $-18.28 * *$ \\
\hline Angha x Pusa-120 & $42.38 * *$ & $27.61 * *$ & $13.61 * *$ & 3.73 & -0.87 & $-19.13 * *$ & 0.43 & $-4.12 * *$ \\
\hline Angha $x$ Pant $T-5$ & $28.37 * *$ & 1.59 & $13.49 * *$ & $13.31 * *$ & -0.77 & $-18.48 * *$ & $14.51 * *$ & $13.15 * *$ \\
\hline SolanVajra x ArkaAbha & $18.57 * *$ & $16.54 * *$ & $10.94 * *$ & 5.84 & $44.42 * *$ & $27.26 * *$ & $28.06 * *$ & $23.30 * *$ \\
\hline SolanVajra x Pusa-120 & $16.29 * *$ & $14.85 * *$ & $-20.03 * *$ & $-32.43 * *$ & $-10.43 * *$ & $-19.48 * *$ & $9.32 * *$ & 0.89 \\
\hline SolanVajra x Pant T-5 & $12.47 * *$ & -1.38 & $-10.66 * *$ & $-17.90 * *$ & $16.30 * *$ & $5.39 *$ & $9.09 * *$ & -2.49 \\
\hline VRT-101 A x ArkaAbha & $22.19 * *$ & $20.82 * *$ & $14.76 * *$ & -1.14 & $31.83 * *$ & $28.16 * *$ & $19.87 * *$ & $16.62 * *$ \\
\hline VRT-101 A x Pusa-120 & $35.76 * *$ & $33.29 * *$ & 2.7 & 0.19 & $-20.24 * *$ & $-20.69 * *$ & $-14.56^{* *}$ & $-20.36^{* *}$ \\
\hline VRT-101 A x Pant T-5 & $13.90 * *$ & 0.4 & $18.66 * *$ & 5.8 & 4.87 & 4.53 & $5.81 * *$ & $-4.52 * *$ \\
\hline VRT-01 x ArkaAbha & -2.16 & $-11.46^{* *}$ & $20.36 * *$ & $6.94 *$ & $-38.59 * *$ & $-56.09 * *$ & $18.26 * *$ & $11.80 * *$ \\
\hline VRT-01 x Pusa-120 & $23.17 * *$ & $8.56 * *$ & 3.21 & $-17.92 * *$ & $-27.67 * *$ & $-47.55 * *$ & $22.63 * *$ & $11.21 * *$ \\
\hline VRT-01 x Pant T-5 & $-32.30 * *$ & $-33.52 * *$ & $9.37 * *$ & -6.1 & $-41.58 * *$ & $-57.40 * *$ & $-22.29 * *$ & $-31.69 * *$ \\
\hline CO-3 x ArkaAbha & $9.99 * *$ & 0.85 & $9.82 * *$ & 1.33 & $-9.66 * *$ & $-36.07 * *$ & -2.85 & $-12.04 * *$ \\
\hline CO-3 x Pusa-120 & 4 & $-7.16 *$ & $10.29 * *$ & $-9.42 * *$ & $9.99 * *$ & $-21.10 * *$ & $17.26 * *$ & 2.06 \\
\hline CO-3 x Pant T-5 & -2.01 & -5.14 & $11.60 * *$ & -0.66 & 3.26 & $-25.52 * *$ & $6.53 * *$ & $-9.99 * *$ \\
\hline VRT-06 x ArkaAbha & $19.94 * *$ & $16.38 * *$ & -1.08 & -1.64 & 5.63 & 3.84 & -2.93 & $-13.28 * *$ \\
\hline VRT-06 x Pusa-120 & $41.83 * *$ & $41.73 * *$ & $-11.44 * *$ & $-21.68 * *$ & $32.50 * *$ & $27.40 * *$ & $35.56 * *$ & $16.50 * *$ \\
\hline VRT-06 x Pant T-5 & $15.16 * *$ & -0.15 & $-8.45 *$ & $-11.49 * *$ & $-9.04 * *$ & $-13.29 * *$ & $-7.76 * *$ & $-23.01 * *$ \\
\hline H-88-78-1 x ArkaAbha & $11.11 * *$ & $7.62 *$ & $29.34 * *$ & $25.00 * *$ & $6.38 * *$ & $-22.52 * *$ & $-22.53 * *$ & $-25.98 * *$ \\
\hline H-88-78-1 x Pusa-120 & $18.16 * *$ & $11.24 * *$ & -3.46 & $-12.40 * *$ & $26.41 * *$ & $-6.58 * *$ & $-13.09 * *$ & $-20.38 * *$ \\
\hline H-88-78-1 x Pant T-5 & 1.93 & $-6.60 *$ & -1.77 & -2.3 & -2.1 & $-27.22 * *$ & $-16.52 * *$ & $-25.91 * *$ \\
\hline S.E.Diff & 0.39 & 0.45 & 0.16 & 0.18 & 0.60 & 0.69 & 5.83 & 6.74 \\
\hline CD $95 \%$ & 0.79 & 0.91 & 0.32 & 0.37 & 1.21 & 1.40 & 11.74 & 13.56 \\
\hline
\end{tabular}


The relative heterosis measured over the mid parental value for number of fruits per cluster varied from -20.03 (Solan Vajra $\times$ Pusa-120) to $29.34 \%$ (H-88-78-1 $\times$ Arka Abha). Regarding heterobeltiosis, the range varied from -32.43 (SolanVajra $\times$ Pusa-120) to 25.00 $\%$ (H-88-78-1 $\times$ Arka Abha). Among the crosses, four crosses displayed significant heterosis in positive direction with maximum per cent of significant heterobeltiosis in the positive direction being recorded in cross $\mathrm{H}$ 88-78-1 × Arka Abha (25.00 \%) followed by Angha $\times$ Arka Abha (15.57\%) and Angha $\times$ Pant T-5 (13.31\%). The results from the work done by Rao et al., (2007) and Gul et al., (2010)revealed similar findings showing significant positive heterosis over mid parent and better parent for number of fruits per cluster in tomato.

For number of fruits per plant, the heterosis over mid parent and better parent was found to be within the range -41.58 (VRT-01 $\times$ Pant T-5) to $44.42 \%$ (Solan Vajra $\times$ Arka Abha) and $-57.40($ VRT-01 $\times$ Pant T-5) to $28.16 \%$ (VRT-101-A $\times$ Arka Abha) respectively. Among all the cross combinations, 10 hybrids over mid parent and only five crosses over better parent exhibited positive significant heterosis. Highest per cent of significant average heterosis was observed in the cross Solan Vajra $\times$ Arka Abha (44.42 \%) followed by CTS-07 $\times$ Arka Abha (32.95\%) and VRT$06 \times$ Pusa-120 (32.50 \%). Maximum significant heterobeltiosis was observed in cross VRT-101-A $\times$ Arka Abha (28.16 \%) followed by VRT-06 $\times$ Pusa-120 $(27.40 \%)$ and Solan Vajra $\times$ Arka Abha (27.26 \%). Significant positive heterosis over mid parent and better parent for this trait was reported by Singh et al., (2007); Kumari et al., (2010); Chauhan et al., (2014); Gowda et al., (2019); and Salim et al., (2019) for number of fruits per plant in tomato which suggested scope for yield improvement.
Heterosis over mid parent and better parent for fruit yield was observed to be significant in both the direction. The mid parent heterosis for this character varied from -22.53 to 35.56 per cent in cross H-88-78-1 $\times$ Arka Abha and VRT-06 $\times$ Pusa-120 respectively. Out of 24 crosses, 13 crosses expressed significant heterosis over mid parent in the desired direction. The cross VRT-06 $\times$ Pusa-120 (35.56\%) expressed maximum percent of significant relative heterosis followed by Solan Vajra $\times$ Arka Abha (28.06 \%) and CTS$07 \times$ Pusa-120 (23.14 \%). Eight $F_{1}$ 's out of 24 crosses expressed positive significant heterosis over better parent ranging from 31.69 (VRT-01 × Pant T-5) to $23.30 \%$ (Solan Vajra $\times$ Arka Abha). The cross combinations Solan Vajra $\times$ Arka Abha, CTS-07 $\times$ Arka Abha and VRT-101-A $\times$ Arka Abha exhibited maximum per cent of positive significant heterobeltiosis in the extent of 23.30, 19.22 and $16.62 \%$ respectively. Similar results in case of tomato were also reported by Ahmed et al., (2011); Agarwal et al., (2014); Gowda et al., (2019); and Salim et al., (2019) for improved fruit yield.

The preponderance of both additive and nonadditive gene actions for yield, its components and quality parameters is greatly suggested for both selection and heterosis breeding for the improvement of tomato crop. From the present study, it was observed that the cross VRT-101-A $\times$ Pant T-5 followed by CTS-07 $\times$ Arka Abha was found to have high significant negative heterosis over both the mid and better parent in case of days to $50 \%$ flowering which is considered desirable, cross combination of Solan Vajra $\times$ Arka Abha was having highly significant heterosis over both the mid parent and better parent for number of primary branches, number of fruits per plant and fruit yield. The heterosis over mid and better parent was significantly high in case of plant height and number of primary branches per plant was observed for the cross CTS-07 
$\times$ Pusa-120. Thus, hybrids exhibiting highly significant heterosis in the desired direction for yield and other yield attributing characters should be given focus for utilizing it in further breeding programme and evaluation and making it preferable for commercial cultivation.

\section{References}

Agarwal, A., Arya, D. N.and Ahmed, Z. 2014. Genetic variability studies in tomato (Solanum lycopersicum L.). Progressive Horticulture, 46(2): 358361.

Ahmad, S., Quamruzzaman, A. K. M. and Islam, M. R. 2011. Estimate of heterosis in tomato (Solanum lycopersicum L.). Bangladesh Journal of Agricultural Research, 36(3): 521527.

Amin, A., Wani, K. P., Dar, Z. A., Jabeen, N. and Mushtaq, F. 2017. Heterosis studies in tomato (Solanum lycopersicum L.). Journal of Pharmacognosy and Phytochemistry, 6(6): 2487-2490.

Chaudhary B. 1996. Exploitation of heterosis in tomato yield and components. South Indian Horticulture,49: 59-85.

Chauhan, V. B. S., Behera, T. K. and Yadav, R. K. 2014. Studies on heterosis for yield and its attributing traits in tomato (Solanum lycopersicum L.). International Journal of Agriculture, Environment and Biotechnology, 7(1): 95.

Dagade, S. B., Barad, A. V., Dhaduk, L. K. and Hariprasanna, K. 2015. Heterosis and inbreeding depression for fruit yield and related characters in tomato (Lycopersicon esculentum Mill.). International Journal of Research in Biosciences, 4:21-28.

Gowda, A. S., Jagadeesha, R. C., Sathish, D., Naik, N., Kantaraju, V. and Hadimani,
H. P. (2019). Study of heterosis in tomato for yield components. International Journal of Chemical Studies, 7(1): 125-127.

Gul, R., Rahman, H., Khalil, I. H., Shah, S. M. A. and Ghafoor, A. 2010. Heterosis for flower and fruit traits in tomato (Lycopersicon esculentum Mill.). African Journal of Biotechnology, 9(27): 4144-4151.

Hedrick, U. P. and Booth, N. 1907.Mendelian characters in tomato. Proceedings of American Society of Horticultural Sciences, 5: 19-23.

Islam, M. R., Ahmad, S. and Rahman, M. M. 2012. Heterosis and qualitative attributes in winter tomato (Solanum lycopersicum L.) hybrids. Bangladesh Journal of Agricultural Research, 37(1): 39-48.

Kumari, N., Srivastava, J. P. and Singh, B. 2010. Heterotic expression for yield and its component in tomato (Lycopersicon esculentum Mill). Annals of Horticulture, 3(1): 98-101.

Kurian, A., Peter, K. V. and Rajan, S. 2006. Heterosis for yield components and fruit characters in tomato. Journal of Tropical Agriculture, 39(1): 5-8.

Mohamed, S., Ali, E. and Mohamed, T. 2012. Study of Heritability and Genetic Variability among Different Plant and Fruit Characters of Tomato (Solanum lycopersiconL.).International Journal of Advanced Scientific and Technical Research, 1: 55-58.

Panse, V. G., Sukhatme, P. V. 1967. Statistical methods for agricultural workers, Indian Council of Agricultural Research, New Delhi. 695p.

Patwary, M. A., Rahman, M. M., Ahmad, S., Miah, M. K. and Barua, H. 2013. Study of heterosis in heat tolerant tomato (Solanum lycopersicum) during summer. Bangladesh Journal of 
Agricultural Research, 38(3): 531-544.

Rao, E. S., Munshi A. D, Singh B. and Kumar R. 2007. Studies on heterosis and combining ability for yield and resistance to early blight in tomato. Indian Journal of Horticulture,64:33134.

Salim, M. M. R., Rashid, M. H., Ali, M. R. and Akter, L. 2019. Studies on Character Improvement in Tomato (Solanum lycopersicum L.) by Heterosis. Asian Plant Research Journal, 2(3):1-12.

Sekhar, L., Prakash, B. G., Salimath, P. M., Channayya, P., HiremathSridevi, O. andPatil, A. A. 2010. Implications of heterosis and combining ability among productive single cross hybrids in tomato. Electronic Journal of Plant Breeding, 1(4): 706-711.

Singh, A. K., Pan, R. S. and Rai, M. 2007. Hetrosis for fruit yield and its component in tomato (Solanum lycopersicum). Vegetable Science, 34(1): 108-108.

Singh, J. K., Singh, J. P., Jain, S. K. and Joshi, A. 2004. Correlation and path coefficient analysis in tomato. Progressive Horticulture, 36: 82-86.

Solieman, T. H. I., El-Gabry, M. A. H. and Abido, A. I. 2013. Heterosis, potence ratio and correlation of some important characters in tomato (Solanum lycopersicum L.). Scientia Horticulturae, 150: 25-30.

Tamta, S. and Singh, J. P. 2017. Heterosis in tomato for growth and yield traits. International Journal of Vegetable Science, 24(2): 169-179.

Yadav, S. K., Singh, B. K., Baranwal, D. K. andSolankey, S. S. 2013. Genetic study of heterosis for yield and quality components in tomato (Solanum lycopersicum). African Journal of Agricultural Research, 8(44): 55855591.

\section{How to cite this article:}

Prachi Pattnaik, Anand Kumar Singh, Bajrang Kumar, Diksha Mishra and Binod Kumar Singh. 2020. Studies on the Effect of Heterosis for Yield and Yield Contributing Plant Traits in Tomato (Solanum lycopersicum L.). Int.J.Curr.Microbiol.App.Sci. 9(04): 97-104. doi: https://doi.org/10.20546/ijcmas.2020.904.013 